\title{
Characterisation of the pyrolysis oil derived from bael shell (aegle marmelos)
}

\author{
Monoj Bardalai ${ }^{\dagger}$, Dimbendra Kumar Mahanta ${ }^{2}$ \\ ${ }^{1}$ Department of Mechanical Engineering, Tezpur University, Tezpur, India \\ ${ }^{2}$ Department of Mechanical Engineering, Assam Engineering College, Gauhati University, Guwahati, India
}

\begin{abstract}
In the present work, bael shell (aegle marmelos) is used as the feedstock for pyrolysis, using a fixed bed reactor to investigate the characteristics of the pyrolysis oil. The product yields, e.g., liquid, char and gases are produced from the biomass at different temperatures with the particle size of $0.5-1.0 \mathrm{~mm}$, at the heating rate of $150^{\circ} \mathrm{C} / \mathrm{min}$. The maximum liquid yield, i.e., $36.23 \mathrm{wt} . \%$, was found at $5500^{\circ} \mathrm{C}$. Some physical properties of the pyrolysis oil such as calorific value, viscosity, density, $\mathrm{pH}$, flash point and fire point are evaluated. The calorific value of the bael shell pyrolysis oil was $20.4 \mathrm{MJ} / \mathrm{kg}$, which is slightly higher than the biomass, i.e., $18.24 \mathrm{MJ} / \mathrm{kg}$. The H/C and O/C ratios of the bio-oil were found as 2.3 and 0.56 respectively, which are quite higher than some other bio-oils. Gas Chromatography and Mass Spectroscopy (GC-MS) and Fourier Transform Infra-red (FTIR) analyses showed that the pyrolysis oil of bael shell is mostly composed by phenolic and acidic compounds. The results of the properties of the bael shell pyrolysis oil reveal the potential of the oil as an alternate fuel with the essential upgradation of some properties.
\end{abstract}

Keywords: Bael shell, Elemental analysis, Fixed bed reactor, Proximate analysis, Pyrolysis, Thermogravimetric analysis.

\section{Introduction}

Due to the increasing crisis of conventional fuel and pollution created by burning of fossil fuel, the use of renewable energy has become the only alternate way to mitigate these problems. The renewable energy can be harnessed from its sources directly or by converting it to some other forms. Biomass is one of the easily available sources of renewable energy, which can be used as fuel directly or by converting into liquid through pyrolysis [1]. In pyrolysis process, the biomass is heated up to around $400-700^{\circ} \mathrm{C}$ inside a reactor, in the oxygen free environment, where a lot of chemical reactions take place and thus the biomass converts into three main products, such as liquid, incondensable gas and char. The liquid yield obtained in the biomass pyrolysis is known as pyrolysis oil or bio-oil. The bio-oil has some advantages over solid biomass, e.g., the fuel in liquid form is easier for storage and transportation, as well as the conversion of biomass into liquid form can reduce the pollution and cost of solid waste disposal. However, pyrolysis oils are not suitable for direct use as a transportation fuel, due to some poor properties including water content, oxygen content, viscosity, acidity etc. These properties of pyrolysis oil are comparatively higher than that of the petroleum fuel. On the other hand, the calorific value of the bio-oil is quite lower than that of the petroleum fuel. Therefore, upgradation of these properties is essential in order to make the pyrolysis oil suitable as the transportation or engine oil. Bridgwater (2004) and Qiang et al. (2008) found that the addition of methanol or acetone can significantly reduce the viscosity of the bio-oil $[2,3]$. It was found that, due to the presence of large amount of water and oxygen content, the calorific value of the bio-oil had reduced to about $45 \%$ of the fossil fuel [4]. Frensh and Czernik (2010) found zeolite (ZSM-5) as a suitable catalyst for converting biomass into pyrolysis oil, since using this catalyst in pyrolysis, the oxygenated compounds in the biomass pyrolysis vapour can be converted into hydrocarbon, which leads to reduce the oxygenated compounds in the bio-oil [5]. Qi et al. (2007) reported various techniques in a review article, such as hydrodeoxygenetion, emulsification and steam reforming for the upgradation of bio-oil quality [6].

The characteristics of bio-oil depend on many factors including biomass particle size, pyrolysis temperature, heating rate, vapour residence time, condensing temperature, type of biomass, moisture content in biomass, type of catalyst, sweeping gas and type of reactor [7-9]. The existing publications show that, a wide variety of biomasses have been used as feedstock for the production of
This is an Open Access article distributed under the terms of the Creative Commons Attribution Non-Commercial License (http://creativecommons. org/ licenses/by-nc/3.0/) which permits unrestricted non-commercial use, distribution, and reproduction in any medium, provided the original work is properly cited.
Received December 7, 2015 Accepted March 1, 2016

${ }^{\dagger}$ Corresponding author

Email: monojb@tezu.ernet.in

Tel: +91-3712-275860

Copyright (C) 2016 Korean Society of Environmental Engineers 
pyrolysis oil, such as woods, agricultural residues, organic wastes and aquatic plants [10]. Different types of reactors are found applicable for pyrolysis process, which includes fixed bed reactor, fluidised-bed reactor, ablative reactor, auger reactor, vacuum pyrolysis reactor, rotating cone reactor, pyros reactor, plasma reactor, microwave reactor and solar reactor. Among all these reactors, the fixed bed reactor is found as simple and reliable, which can produce similar kind of products as produced by the other type of reactors $[9,11]$.

The bael is a widely available common fruit in the state of Assam along with the rest part of India. Mostly, the inner part under the shell of the bael is used as fruit, which can be eaten directly or after drying or boiling when it ripens. The bael fruit can be used for different medicinal purposes, such as gastrointestinal diseases, piles, oedema, jaundice, vomiting, obesity, paediatric disorders, gynaecological disorders, urinary complaints and as a rejuvenate. However, the shell of the bael fruit is disposed as a waste material after using its inner portion. Therefore, in this work, the bael shell has been used as the feedstock for producing pyrolysis oil, and some physical and chemical properties of the oil are evaluated and analysed.

\section{Materials and Methods}

\subsection{Preparation of Feedstock}

The feedstock, i.e., bael shell, was collected from the southwest part of Assam (India), and ground in a grinding machine (BAJAJ PLATINI, Model: PX 7 MIXER GRINDER). A mechanical sieve shaker (IKON ${ }^{\mathrm{TM}}$ instrument) was used along with the standard test sieve (SETHI, as per IS: 460) to prepare the feedstock in the range of $0.5-1.0 \mathrm{~mm}$. Before feeding in the reactor, the feedstock was dried in the sunlight for $24 \mathrm{~h}$ to reduce its moisture content.

\subsection{Proximate Analysis}

In order to perform the proximate analysis of the bael shell biomass, ASTM D-271-48 standard was used to determine its ash content, volatile matter and fixed carbon. The moisture content was determined as received basis. For determination of cellulose, hemicellulose and lignin of the biomass, the thermogravimetric technique was used according to Gercìa Perèz et al. [12].

\subsection{Elemental Analysis}

The elemental analysis of the biomass and pyrolysis oil was conducted in a CHN analyser (Perkin Elmer, series- ii).

The calorific values of both biomass and pyrolysis oil are determined with the help of Automatic Bomb Calorimeter (Model 5E-1 AC/ML, Changha Kaiyuan Instrument Co-Ltd.)

\subsection{Thermogravimetric Analysis (TGA)}

The thermogarvimetric analysis was conducted in a TGA analyser (SHIMADZU, TGA-50) in nitrogen atmosphere under the flow of $\mathrm{N}_{2}$ at the rate of $30 \mathrm{~mL} / \mathrm{min}$. About $4.68 \mathrm{mg}$ of biomass was used for the experiment, and the sample was heated from the room temperature to $600^{\circ} \mathrm{C}$, at the rate of $10^{\circ} \mathrm{C} / \mathrm{min}$.

\subsection{X-Ray Diffraction (XRD)}

The XRD analyses for both biomass and biochar were conducted on an analytical XRD diffractometer (RIGAKU Mini flex, Japan). The X-ray diffractometer was operated at a voltage of $30 \mathrm{kV}$ with a current density of $15 \mathrm{~mA}$. The scanning range was from $2 \theta$ $=10^{0}$ to $70^{0}$ with the scan speed of $0.05^{\circ} / \mathrm{s}$.

\subsection{Viscosity, Density and Water Content}

The viscosity and density are two major properties of the bio-oil, which determine the flow characteristics of the fuel. Both the properties are measured with the help of a digital instrument (LEMIS Instrument, VISCODENS, VDM 300).

In order to determine the water content in bio-oil, the Dean and Stark Apparatus (As per IP specification) was used. For complete separation of water, the experiment was run for around $24 \mathrm{~h}$.

\section{7. $\mathrm{pH}$ Value, Flash Point and Fire Point}

The $\mathrm{pH}$ value of the bio-oil was determined with help of a $\mathrm{pH}$ meter (SYSTRONICS, Digital pH Meter 802).

In order to measure the flash point and fire point of the pyrolysis oil, an open cup digital tester (REICO EQUIPMENT AND INSTRUMENT PVT. LTD, model RFFP) was used.

\subsection{GC-MS and FTIR}

Gas chromatography-mass spectrometry (GC-MS) was conducted to elucidate the molecular identity of compounds. Briefly, GC-MS (Perkin Elmer, GC-Clarus 600, MS-Clarus $600 \mathrm{C}$ ) equipped with a quadrupole ion trap mass detector coupled with Elite-5 MS (0.25 $\mathrm{mm}$ i.d. $\times 30 \mathrm{~m}$ length) capillary column, ionization energy of $70 \mathrm{eV}$, scan interval of $1.5 \mathrm{~s}$ and mass range of 50-600 amu was used. The oven temperature was programmed at $120^{\circ} \mathrm{C}$ for 1.0

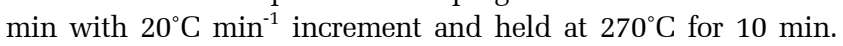
The temperature of both the detector and the injector was kept at $270^{\circ} \mathrm{C}$. The FTIR analysis was carried out using a FTIR instrument (NICOLET, Impact 410) with a resolution of $4 \mathrm{~cm}^{-1}$.

\subsection{Production of Pyrolysis Oil}

The production of pyrolysis oil was carried out in a lab scale pyrolysis plant developed in Tezpur University, Assam, India, as shown in Fig. 1. The main components of the pyrolysis plant include a fixed bed reactor, a clamp type tubular furnace $(2 \mathrm{~kW})$, a glass condenser, a $\mathrm{N}_{2}$ gas cylinder and a temperature controller. The reactor is made of stainless steel and the major part of the reactor is cylindrical in shape with a conical head. The inside and outside diameter of the cylindrical part of the reactor are $88 \mathrm{~mm}$ and $100 \mathrm{~mm}$ respectively. The length of the cylindrical portion is $150 \mathrm{~mm}$ whereas the conical head length is $100 \mathrm{~mm}$. A small opening with a diameter of $27 \mathrm{~mm}$ was made at the top of the conical head of the reactor for feeding the biomass into the reactor. The tubular furnace, which is made of ceramic and stainless steel covers the major portion of the reactor and enhances uniform heating to the biomass particles.

The bael shell was taken as the feedstock for pyrolysis, which was placed gently in the reactor taking the amounts of 50-80 g at different runs. The temperature was programmed at $15^{\circ} \mathrm{C}$ for 


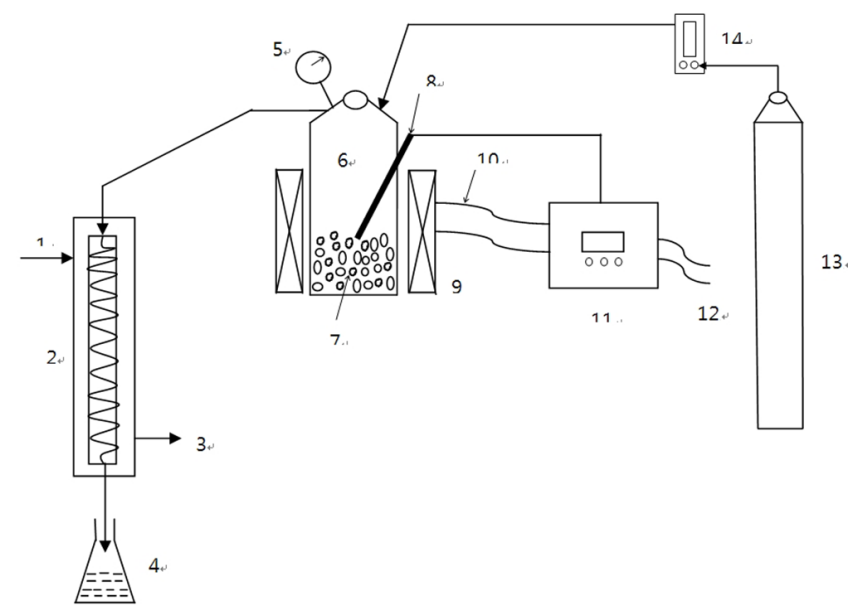

Fig. 1. Block diagram of the lab scale pyrolysis plant.

1.0 min with $15^{\circ} \mathrm{C} \min ^{-1}$ increment and held at $450^{\circ} \mathrm{C}, 500^{\circ} \mathrm{C}$, $550^{\circ} \mathrm{C}$ and $600^{\circ} \mathrm{C}$, for at least $30 \mathrm{~min}$ in each case. During experiment, nitrogen gas was supplied at the flow rate of $50 \mathrm{~mL} \mathrm{~min}{ }^{-1}$ intermittently to enhance the flow of vapor produced inside the reactor. The pyrolysis vapor was allowed to pass through the condenser with cold water inflowing at the temperature of $150^{\circ} \mathrm{C}$. The condensed liquid was collected in a container at the end of the experiment. The operating pressure in the reactor was maintained at $0.5 \mathrm{MPa}$ during pyrolysis. As the reactor cooled down to the room temperature, the conical head of the reactor was unscrewed and the char that stored inside the reactor was collected. After each experiment, the inner surface of the reactor was cleaned to prepare it for the next run. At each temperature, the experiments were carried out three times, and the average amounts of yields are taken. For various kinds of analyses, the pyrolysis oil produced at the temperature of $4500^{\circ} \mathrm{C}$ is considered in this study.

All the above mentioned analyses for the physical and chemical properties of biomass as well as the pyrolysis oil were conducted at least three times, and the average results are reported.

\section{Results and Discussion}

\subsection{Biomass Characterisation}

\subsubsection{Proximate and elemental analysis}

The results of proximate and elemental analyses of bael shell biomass are shown in Table 1. The bael shell shows very higher amounts of volatile matter as compared to other biomasses, which indicates the presence of significant amounts of cellulose and hemicellulose in the biomass. From Table 1, the fixed carbon of bael shell is seen lower in comparison to the other biomasses. This is due to the higher amount of volatile matter, since fixed carbon is the remaining residue after volatilization. The ash content of bael shell is found lower than rice husk, rice straw and soybean (Table 1), which indicates its suitability as a feedstock for bio-oil production. The calorific value of the bael shell is found within the range of $16-24.5 \mathrm{MJ} / \mathrm{kg}$, which is found in several kinds of biomasses, such as rice straw, bamboo sawdust and rapeseed cake $[4,13,14,15,16]$. The calorific value of the biomass depends on several parameters, such as type of biomass, amount of moisture, oxygen, carbon and hydrogen content present in it. In bael shell,

Table 1. Proximate and Elemental Analysis of the Biomass

\begin{tabular}{|c|c|c|c|c|c|c|c|c|}
\hline Proximate analysis & $\begin{array}{c}\text { Rice husk } \\
{[16]}\end{array}$ & $\begin{array}{c}\text { Rice straw } \\
{[16]}\end{array}$ & $\begin{array}{l}\text { Sweet sorghum } \\
\text { bagasse [17] }\end{array}$ & $\begin{array}{c}\text { Soybean } \\
{[15]}\end{array}$ & $\begin{array}{l}\text { Pine saw } \\
\text { dust [4] }\end{array}$ & Bael shell & $\begin{array}{c}\text { Mesquite } \\
\text { saw dust [4] }\end{array}$ & $\begin{array}{l}\text { Wheat } \\
\text { shell [4] }\end{array}$ \\
\hline Moisture (wt.\%) & 1.3 & 4.1 & 4.17 & 9.5 & 10.2 & 11.68 & 12.5 & 18.8 \\
\hline Volatile matter (wt.\%) ${ }^{\mathrm{db}}$ & 69.3 & 74.3 & 76.33 & $69.28 \mathrm{wb}$ & -- & 91.42 & -- & -- \\
\hline Fixed carbon (wt.\%) ${ }^{\mathrm{db}}$ & 16.8 & 16 & 15.98 & $14.92 \mathrm{wb}$ & -- & 2.94 & -- & -- \\
\hline Ash (wt.\%) ${ }^{\mathrm{db}}$ & 13.9 & 9.8 & 3.53 & $6.30 \mathrm{wb}$ & 0.3 & 5.64 & 0.6 & 5.4 \\
\hline \multicolumn{9}{|c|}{ Lignocellulosic material composition in water and ash free basis (wt.\%) } \\
\hline Cellulose & --- & --- & 34.2 & --- & $35^{\mathrm{a}}$ & 40 & $40-45^{b}$ & $10-15^{\mathrm{c}}$ \\
\hline Hemicellulose & --- & --- & 24.3 & --- & $29^{\mathrm{a}}$ & 28 & $25-30^{\mathrm{b}}$ & $30^{\mathrm{C}}$ \\
\hline Lignin & --- & --- & 6.5 & --- & $28^{\mathrm{a}}$ & 30 & $11-28^{\mathrm{b}}$ & $4-8^{\mathrm{C}}$ \\
\hline Calorific value (MJ/kg) & 16.8 & 18.6 & 18.57 & 18.17 & 15.4 & 18.24 & 15.4 & 14.1 \\
\hline \multicolumn{9}{|c|}{ Elemental Analysis } \\
\hline Carbon(wt. \%) & 50.4 & 54.3 & 45.71 & 41.7 & 51.6 & 40.67 & 53.0 & 46.8 \\
\hline Hydrogen (wt. \%) & 6 & 5.7 & 5.80 & 6.17 & 5.2 & 6.23 & 4.8 & 6.0 \\
\hline Nitrogen (wt. \%) & 0.9 & 1.6 & 0.33 & 7.14 & -- & 1.34 & 0.6 & 3.4 \\
\hline Oxygen by difference (wt. \%) & 42.6 & 38.4 & 48.16 & 44.99 & 43.2 & 51.76 & 41.6 & 43.8 \\
\hline $\mathrm{H} / \mathrm{C}$ & -- & -- & 0.13 & 1.78 & -- & 1.83 & -- & -- \\
\hline $\mathrm{O} / \mathrm{C}$ & -- & -- & 1.05 & 0.81 & -- & 0.95 & -- & -- \\
\hline
\end{tabular}

${ }^{\mathrm{db}}$ : dry basis, wb: wet basis

${ }^{\mathrm{a}}$ From Ref. 17, ${ }^{\mathrm{b}}$ From Ref. 18, ${ }^{\mathrm{c}}$ From Ref. 19 
although the water and oxygen contents are found higher as compared to some biomasses, possibly due to higher amount of hydrogen content its calorific value is quite comparable with the other biomasses including soybean, rice straw and sweet sorghum as reported in Table $1[15,16,17]$.

\subsubsection{Thermal degradation analysis}

The TGA and Derivative Thermogravimetric (DTG) profiles of bael shell are shown in Fig. 2. The moisture removal and evaporation of light volatiles in the biomass can be seen up to $200^{\circ} \mathrm{C}$, from the TG profile. The main decomposition of cellulosic biomass occurs at around $300^{\circ} \mathrm{C}$. From the TG profile, it is observed that, maximum thermal degradation of the biomass has occurred between $240^{\circ} \mathrm{C}$ and $345^{\circ} \mathrm{C}$, which reveal the decomposition of cellulose and hemicellulose in this region. The hemicellulose decomposes upto $250^{\circ} \mathrm{C}$, whereas, the cellulose decomposes between $250-350^{\circ} \mathrm{C}$ [21]. The highest peak observed around $259^{\circ} \mathrm{C}$ in the DTG curve can be attributed to the decomposition of cellulose. It was found that, the maximum thermal decomposition of softwood biomass occurs at lower temperature, whereas, the hardwoods show significant thermal decomposition at higher temperature [22].

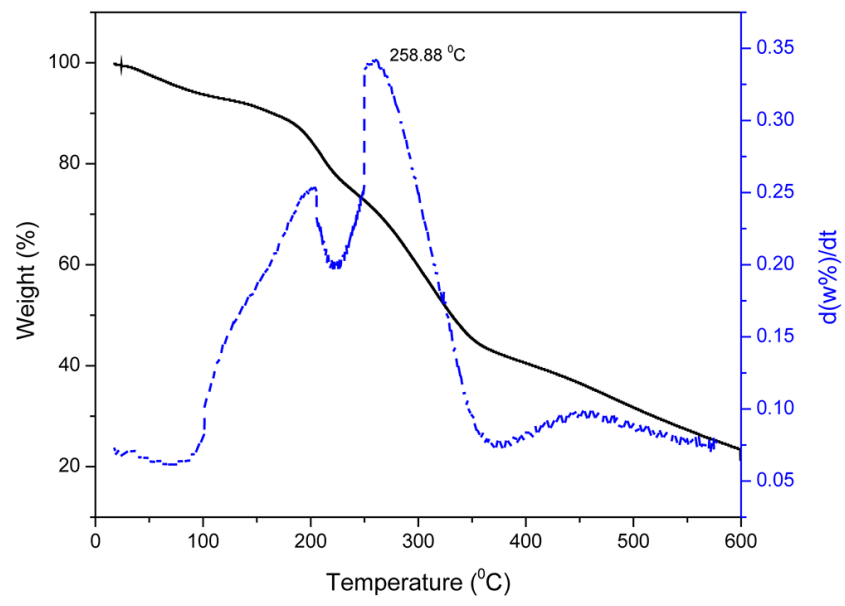

Fig. 2. TGA and DTG of bael shell.

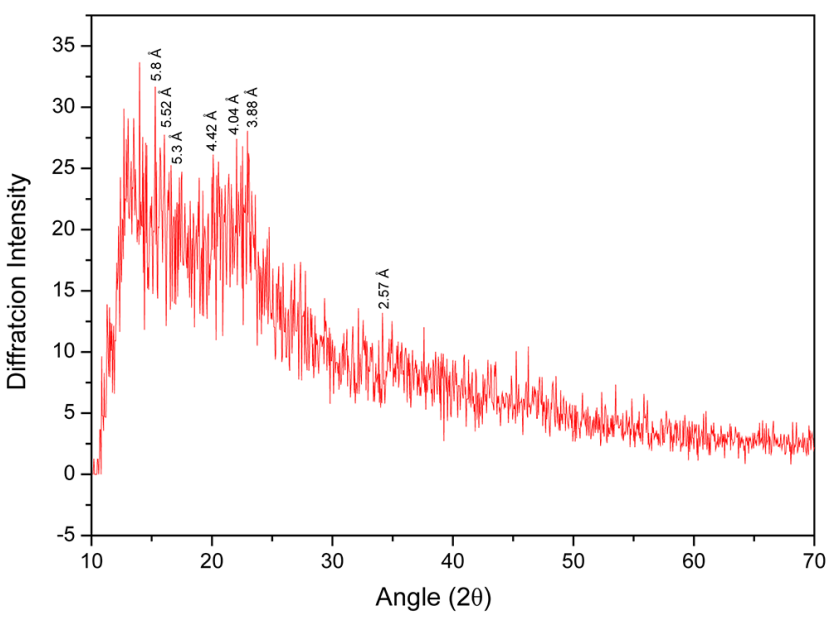

Fig. 3. XRD of bael shell.
After $350^{\circ} \mathrm{C}$, further decreasing of the TG curve indicates the decomposition of lignin present in the biomass. Since, lignin consists of benzene rings, and thus becomes more aromatic as compared to cellulose and hemicellulose, and therefore, it requires more thermal energy to break the bonds [23, 24]. This indicates that, the minimum pyrolysis temperature required for bael shell is $346-350^{\circ} \mathrm{C}$.

\subsubsection{XRD analysis}

The X-ray diffraction pattern of bael shell as displayed in Fig. 3, clearly shows the amorphous behaviour. However, it shows some local crystalline structure with high conjugated aromatic compounds [25]. The peak spacing observed at $5.8 \AA, 5.52 \AA, 5.3 \AA, 4.42 \AA, 4.04 \AA$, $3.88 \AA$ and $2.57 \AA$ in the XRD pattern of bael shell can be assigned to the presence of crystal structure of cellulose [26, 27, 28].

\subsection{Influence of Temperature on Pyrolysis Yields}

The trend of variation of pyrolysis oil and char with temperature can be seen from the curves plotted in Fig. 4. It has been observed that, the temperature plays a significant role on the product yields of pyrolysis. The major product of the pyrolysis, i.e., the liquid yield, has found to be maximum within the temperature range of $500-550^{\circ} \mathrm{C}$. The highest amount of liquid yield was found as 37.23 wt. $\%$ at $550^{\circ} \mathrm{C}$. This amount of the liquid yield produced at $550^{\circ} \mathrm{C}$ is quite higher than that of the previously reported range, e.g., 20-26 wt.\% [15, 29, 30, 31]. This can be attributed due to higher volatile matter present in the biomass, which is an agreement of the proximate analysis of biomass. The char and gas yields show decreasing and increasing trend respectively, from 500 to $600^{\circ} \mathrm{C}$, similar to the trend reported by Sundaram and Natarjan, Ates et al. and Demiral et al. [13, 29, 31]. With the increase of temperature, the decrease of char and increase of gas respectively, is due to the secondary cracking of char and pyrolysis vapour. At higher temperature, such as about $600^{\circ} \mathrm{C}$ and above, the decrease in liquid yield is due to secondary destruction of tar and pyrolysis vapour, which leads to increase the incondensable gases [31, 32]. The liquid yield continuously found increasing upto $5500^{\circ} \mathrm{C}$ as the result of complete decomposition of hemicellulose and cellulose and partial decomposition of lignin. At the lower temperature, such as $450^{\circ} \mathrm{C}$ and below, the liquid yield is found lower, due to incomplete pyrolysis of the biomass.

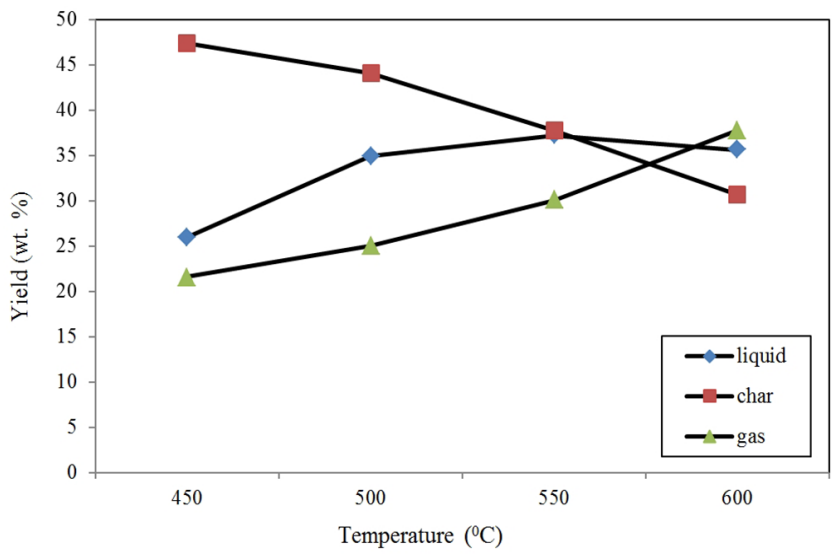

Fig. 4. Variation of pyrolysis product yields with temperature. 


\subsection{Characterization of the pyrolysis Oil}

\subsubsection{Physical properties}

Table 2 shows the various physical properties of the pyrolysis oil derived from bael shell in comparison to some other bio-oils. The calorific value of the bael shell pyrolysis oil is found higher than some other bio-oils. However, the bio-oils of rice straw and soybean have higher calorific value than bael shell pyrolysis oil as reported in Table 2. This is due to the higher oxygen and water content present in the bio-oil of bael shell than both rice straw and soybean, because, the increase of oxygen and water content leads to decrease the calorific value of a fuel. Further, in case of wheat shell bio-oil (Table 2), even very lower amount of oxygen, the calorific value was found quite lower, which is possibly due to large amount of water content present in the bio-oil.

It is observed that, the $\mathrm{O} / \mathrm{C}$ ratio has decreased from 0.95 in the feedstock, to 0.56 in the bio-oil, (see Table 1 and 2) which indicates the production of less oxygenated and more carbonaceous liquid fuel. This $\mathrm{O} / \mathrm{C}$ ratio of bael shell bio-oil is quite comparable with rice husk bio-oil, as seen in Table 2. The $\mathrm{H} / \mathrm{C}$ ratio of bael shell bio-oil is higher than the all other bio-oils as reported in Table 2. Moreover, H/C ratio of bael shell pyrolysis oil can be compared to n-pentane fraction of sesame stalks oil with $\mathrm{H} / \mathrm{C}$ ratio of 2.12, and gasoline [29].

The flash point of bael shell pyrolysis oil has found to be $88^{\circ} \mathrm{C}$ (Table 2), which can be compared with the bio-oil of rapeseed with the flash point $83^{\circ} \mathrm{C}$ [14]. Further, the flash point of bael shell bio-oil has found consistent with the diesel fuels, which normally lies between 52 and $96^{\circ} \mathrm{C}$. The fire point of the bael shell bio oil was found as $98^{\circ} \mathrm{C}$, which is exactly $10^{\circ} \mathrm{C}$ higher than the flash point.

The $\mathrm{pH}$ value of the bael shell bio-oil is quite similar to the rice husk bio-oil, as seen in Table 2 . This lower $\mathrm{pH}$ value indicates the presence of a significant amount of acid contents in the bio-oil. It was found that, the pyrolysis oil derived from ligoncellulosic biomasses generally shows the acidic characteristic [16]. Further, the $\mathrm{pH}$ value of bael shell bio-oil is quite comparable with some other bio-oils, such as mesquite saw dust, pine saw dust, sweet sorghum bagasse, rice straw and soybean, as found in Table 2.

The kinematic viscosity of the bael shell pyrolysis oil was measured at $400^{\circ} \mathrm{C}$ and $600^{\circ} \mathrm{C}$ and the same are reported in Table 2. From these results, it is easily noticed that the kinematic viscosity has decreased with the increase of temperature, which is similar to the trend observed by Qiang et al. [3]. From Table 2, it is clearly seen that the kinematic viscosity of bael shell pyrolysis oil is quite lower than rice husk and rice straw bio-oil, although it is slightly higher than the bio-oil of sweet sorghum bagasse. The difference of these results could be due to the variation of water content present in the bio-oils, since the increase of water content in bio-oil leads to decrease the kinematic viscosity.

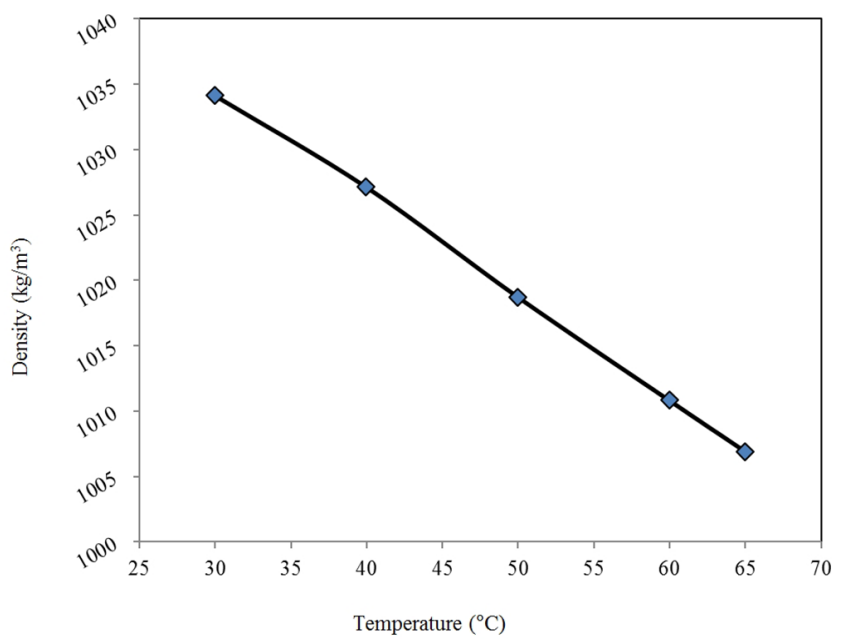

Fig. 5. Variation of density of pyrolysis oil with temperature.

Table 2. Physical Properties of Pyrolysis Oil

\begin{tabular}{|c|c|c|c|c|c|c|c|c|}
\hline Properties & $\begin{array}{c}\text { Wheat shell } \\
{[4]}\end{array}$ & $\begin{array}{c}\text { Mesquite } \\
\text { saw dust [4] }\end{array}$ & $\begin{array}{c}\text { Pine saw } \\
\text { dust [4] }\end{array}$ & $\begin{array}{c}\text { Sweet sorghum } \\
\text { bagasse [17] }\end{array}$ & $\begin{array}{c}\text { Rice husk } \\
\text { [16] }\end{array}$ & Bael shell & $\begin{array}{c}\text { Rice straw } \\
{[16]}\end{array}$ & $\begin{array}{c}\text { Soybean } \\
\text { [15] }\end{array}$ \\
\hline $\begin{array}{l}\text { Higher Calorific value, as } \\
\text { produced basis (MJ/kg) }\end{array}$ & 6.02 & 7.72 & 10.03 & 12.39 & 19.4 & 20.4 & 22.1 & 33.6 \\
\hline \multicolumn{9}{|c|}{ Elemental Analysis } \\
\hline $\mathrm{C}$ & 69.9 & 59.4 & 45.8 & 22.08 & 58.9 & 50.80 & 64.1 & 67.89 \\
\hline $\mathrm{H}$ & 9.7 & 5.8 & 8.7 & 6.52 & 7.0 & 10.09 & 7.6 & 7.77 \\
\hline $\mathrm{N}$ & 11.5 & 0.3 & 0.2 & 0.21 & 0.9 & 0.33 & 0.8 & 10.84 \\
\hline O (by difference) & 8.8 & 34.5 & 45.3 & 71.2 & 39.4 & 37.97 & 27.3 & 13.5 \\
\hline $\mathrm{H} / \mathrm{C}$ & 1.90 & 1.49 & 2.28 & 0.3 & 1.2 & 2.3 & 1.4 & 1.37 \\
\hline $\mathrm{O} / \mathrm{C}$ & 0.07 & 0.45 & 0.74 & 3.22 & 0.5 & 0.56 & 0.3 & -- \\
\hline Flash point & -- & -- & -- & -- & -- & $88^{\circ} \mathrm{C}$ & -- & 63 \\
\hline Fire point & -- & -- & -- & -- & -- & $98^{\circ} \mathrm{C}$ & -- & -- \\
\hline $\mathrm{pH}$ & 6 & 3 & 3 & 2.84 & 2.9 & 2.9 & 3.4 & -- \\
\hline \multicolumn{9}{|c|}{ Kinematic viscosity (cSt) } \\
\hline at $40^{\circ} \mathrm{C}$ & -- & -- & -- & 1.89 & 10.3 & 3.56 & 13.3 & -- \\
\hline at $60^{\circ} \mathrm{C}$ & -- & -- & -- & 1.23 & -- & 2.33 & -- & -- \\
\hline Water content (wt.\%) & 84.4 & 67.6 & 49.60 & 56.29 & 23.46 & 40.5 & 22.14 & 0 \\
\hline
\end{tabular}


The variation of density of bael shell pyrolysis oil with temperature is shown in Fig. 5. The density of the bael shell pyrolysis oil at $30^{\circ} \mathrm{C}$ is found to be $1034.1 \mathrm{~kg} / \mathrm{m}^{3}$ and it has decreased continuously with the increase of temperature. These results are found within the range of the density of many bio-oils available in the literature, e.g., $964-1300 \mathrm{~kg} / \mathrm{m}^{3}$ [14, 33, 34, 35].

\subsubsection{Chemical properties}

The GC-MS analysis was used to identify the major compounds and the chemical structure present in the bael shell pyrolysis oil. Among many small peaks displayed in the GC-MS chromatogram (Fig. 6), the most abundant spectra have been identified with the higher intensities in comparison to remaining as listed in Table 3. In view of the results shown in Table 3, it is found that, pyrolysis oil of bael shell includes the oxygenated hydrocarbons, acids, esters, alcohols and aldehydes originated from the pyrolysis of cellulose and hemicellulose [36]. The other phenolic compounds as shown in Table 3 are found due to the pyrolysis of lignin. The presence of carboxylic acid results the low $\mathrm{pH}$ value of the bio-oil. Further, among the detected compounds, no polycyclic aromatic hydrocarbons were found, which are known as carcinogenic that causes cancer [3]. Due to higher concentrations of phenols, the pyrolytic liquid of bael shell can be considered as the potential raw material in chemical process industries to produce adhesives and phenol substituting agent in phenol-formaldehyde resins [37].

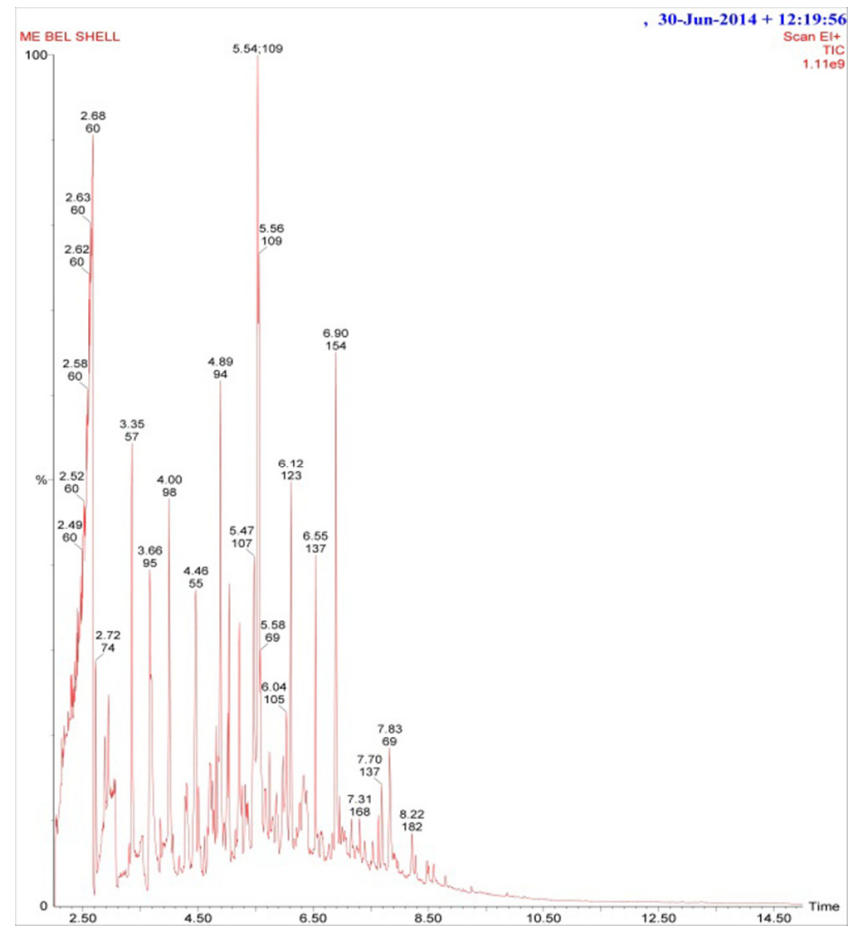

Fig. 6. GC-MS spectrum of bael shell pyrolysis oil.

Table 3. Identified chemical compounds present in pyrolysis oil of bael shell from GC-MS analysis

\begin{tabular}{|c|c|c|c|c|}
\hline Sl No & Retention time (min) & Compound & Molecular weight (g/mol) & Formula \\
\hline 1 & 2.68 & Thietane, 2,4-dimethyl- & 102 & $\mathrm{C}_{5} \mathrm{H}_{10} \mathrm{~S}$ \\
\hline 2 & 2.72 & 2-Methylheptanoic acid & 144 & $\mathrm{C}_{8} \mathrm{H}_{16} \mathrm{O}_{2}$ \\
\hline 3 & 2.94 & 2,3,4-Trimethylpentanoic acid & 144 & $\mathrm{C}_{8} \mathrm{H}_{16} \mathrm{O}_{2}$ \\
\hline 4 & 3.35 & Pentanoic acid, 2-Methyl-3-Oxo-, Methyl ester & 210 & $\mathrm{C}_{7} \mathrm{H}_{12} \mathrm{O}_{3}$ \\
\hline 5 & 3.66 & Pyrimidine-4-Carboxylic acid, 2-Hydroxy-, Methyl ester & 154 & $\mathrm{C}_{6} \mathrm{H}_{6} \mathrm{O}_{3} \mathrm{~N}_{2}$ \\
\hline 6 & 4.00 & Methylene Cyclopropane Carboxylic acid & 98 & $\mathrm{C}_{5} \mathrm{H}_{6} \mathrm{O}_{2}$ \\
\hline 7 & 4.30 & 4,4-Dimethyl-2-cyclopenten-1-one & 110 & C7H10O \\
\hline 8 & 4.46 & N,N-Dinitropiperazine & 176 & $\mathrm{C}_{4} \mathrm{H}_{8} \mathrm{~N}_{4} \mathrm{O}_{4}$ \\
\hline 9 & 4.82 & Silacyclohexadiene-2,5 & 96 & $\mathrm{C}_{5} \mathrm{H}_{8} \mathrm{Si}$ \\
\hline 10 & 4.89 & Phosphonic acid, (P-Hydroxyphenyl) & 174 & $\mathrm{C}_{6} \mathrm{H}_{7} \mathrm{O}_{4} \mathrm{P}$ \\
\hline 11 & 5.05 & Propanoic acid, 2-methyl-,1-(1,1-dimethylethyl)-2-methyl-1,3-pro & 286 & $\mathrm{C}_{16} \mathrm{H}_{30} \mathrm{O}_{4}$ \\
\hline 12 & 5.22 & 2-Ethyl-5-propylcyclopentanone & 154 & $\mathrm{C}_{10} \mathrm{H}_{18} \mathrm{O}$ \\
\hline 13 & 5.47 & Phenol, 3-methyl- & 108 & $\mathrm{C}_{7} \mathrm{H}_{8} \mathrm{O}$ \\
\hline 14 & 5.54 & Phenol, 2-Methoxy & 124 & $\mathrm{C}_{7} \mathrm{H}_{8} \mathrm{O}_{2}$ \\
\hline 15 & 5.56 & Mequinol & 124 & $\mathrm{C}_{7} \mathrm{H}_{8} \mathrm{O}_{2}$ \\
\hline 16 & 5.75 & 2-Cyclopenten-1-one, 3-ethyl-2-hydroxy- & 126 & $\mathrm{C}_{7} \mathrm{H}_{10} \mathrm{O}_{2}$ \\
\hline 17 & 6.04 & Methanol, oxo-, benzoate & 150 & $\mathrm{C}_{8} \mathrm{H}_{6} \mathrm{O}_{3}$ \\
\hline 18 & 6.12 & Phenol, 2-Methoxy-4-Methyl & 138 & $\mathrm{C}_{8} \mathrm{H}_{10} \mathrm{O}_{2}$ \\
\hline 19 & 6.34 & 1,4:3,6-Dianhydro-alpha-D-Glucopyranose & 144 & $\mathrm{C}_{6} \mathrm{H}_{8} \mathrm{O}_{4}$ \\
\hline 20 & 6.55 & Phenol, 4-Ethyl-2-Methoxy & 152 & $\mathrm{C}_{9} \mathrm{H}_{12} \mathrm{O}_{2}$ \\
\hline 21 & 6.90 & Phenol, 2,6-Dimethoxy & 154 & $\mathrm{C}_{8} \mathrm{H}_{10} \mathrm{O}_{3}$ \\
\hline 22 & 7.64 & Methiocarb-anisole & 182 & $\mathrm{C}_{10} \mathrm{H}_{14} \mathrm{O}_{\mathrm{S}}$ \\
\hline 23 & 7.70 & Phenol, 2-methoxy-4-propyl- & 166 & $\mathrm{C}_{10} \mathrm{H}_{14} \mathrm{O}_{2}$ \\
\hline 24 & 7.83 & 2,6-Dimethoxybenzoquinone & 168 & $\mathrm{C}_{8} \mathrm{H}_{8} \mathrm{O}_{4}$ \\
\hline 25 & 8.22 & Benzaldehyde, 4-hydroxy-3,5-dimethoxy- & 182 & $\mathrm{C}_{9} \mathrm{H}_{10} \mathrm{O}_{4}$ \\
\hline
\end{tabular}




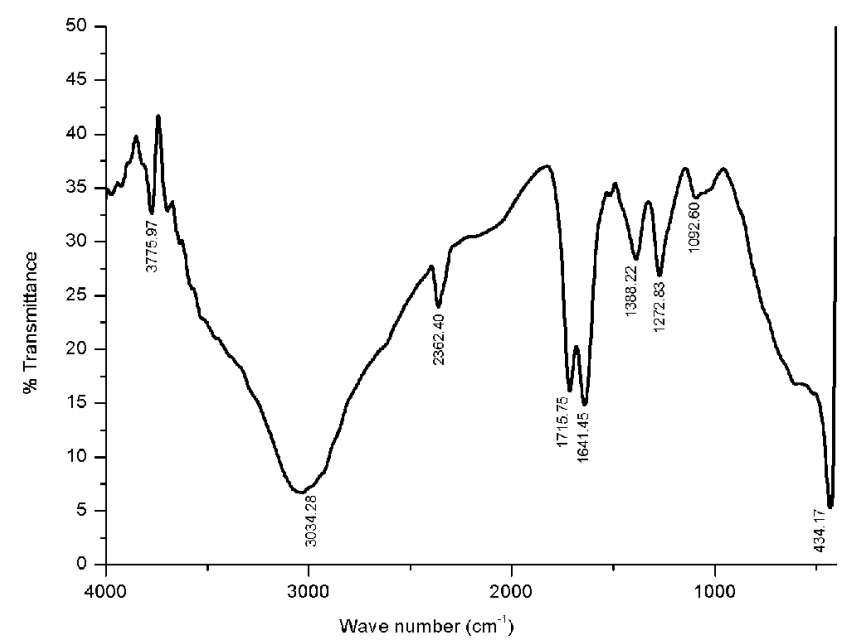

Fig. 7. FTIR of bael shell pyrolysis oil.

The shape, position and intensity of the peaks in the FTIR spectrum, reveal the functional group and structure of the compounds present in the pyrolysis oil. The IR spectrum of the bael shell pyrolysis oil can be seen in Fig. 7. The peaks found between 1000 and $1500 \mathrm{~cm}^{-1}$, confirm the presence of esters, primary, secondary and tertiary alcohol with $\mathrm{C}-\mathrm{O}$ stretching. Another peak found around $1645 \mathrm{~cm}^{-1}$, shows the presence olifinic compounds in the bio-oil, such as aromatic hydrocarbons, phenols and esters with $\mathrm{C}=\mathrm{O}$ stretching vibration [17]. The absorption band in 3040-3000 $\mathrm{cm}^{-1}$ ( $\mathrm{C}=\mathrm{C}$ stretching vibration), clearly indicates the aromaticity of the bio-oil [38]. The peak found in the range of 1650-1750 $\mathrm{cm}^{-1}$, indicates the presence of carboxylic acid $(\mathrm{C}=\mathrm{O}$ stretching vibration together with $\mathrm{C}-\mathrm{H}$ stretching vibrations), which contains carboxyl and hydroxyl functional groups [39]. The peaks found in $1715-1730 \mathrm{~cm}^{-1}$, also indicate the presence of esters with $\mathrm{C}=\mathrm{O}$ stretching vibration.

\section{Conclusions}

The bael shell was pyrolysed using a fixed bed reactor. The distribution of the pyrolysis products are analysed along with the evaluation of physical and chemical properties of the pyrolysis oil as well as the raw biomass. The following conclusions can be highlighted from this work:

- The bael shell is a lignocellulose biomass and the minimum temperature requirement for pyrolysis is $346-350^{\circ} \mathrm{C}$.

- The biochar yield has shown the decreasing trend, while the incondensable gas was found increasing with the increase of pyrolysis temperature. On the other hand, pyrolysis oil yield was found to be maximum in the temperature between 500 and $550^{\circ} \mathrm{C}$.

- The calorific value of biomass pyrolysis oil is higher than the raw biomass. Compared with some bio-oils, the calorific value of bael shell bio-oil is more. However, due to higher amount of oxygen and water content, the calorific value of bael shell pyrolysis oil is quite lower than the petroleum fuels.

- The kinematic viscosity of the bael shell pyrolysis oil is lower as compared to some other bio-oils. The density of the bael shell pyrolysis oil lies within the range of other bio-oils and it shows a decreasing trend with the increasing temperature.

- The $\mathrm{pH}$ value of the pyrolysis oil is 2.9 , which is the indication of acidic nature of the oil. The $\mathrm{O} / \mathrm{C}$ ratio of bael shell pyrolysis oil is lower than the biomass, and thus the pyrolysis oil of bael shell can be considered as less oxygenated and more carbonaceous fuel.

- The GC-MS analysis identified some acidic and alcoholic compounds in the bio-oil. The FTIR analysis identified the carboxyl and hydroxyl functional groups and confirms the GC-MS analysis.

\section{Acknowledgments}

The authors highly acknowledge Tezpur University for the financial support to develop the lab scale pyrolysis experimental setup for performing the experiments and using various laboratory instruments to evaluate the required properties.

\section{References}

1. Bridgwater AV. Principles and practice of biomass fast pyrolysis processes for liquids. J. Anal. Appl. Pyrol. 1999;51:3-22.

2. Bridgwater AV. Biomass fast pyrolysis. Therm. Sci. 2004;8: 21-49.

3. Qiang L, Lai YX, Feng ZX. Analysis on chemical and physical properties of bio-oil pyrolyzed from rice husk. J. Anal. Appl. Pyrol. 2008;82:191-198.

4. Bertero M, Puente G, Sedran U. Fuels from bio-oils: Bio-oil production from different residual sources, characterisation and thermal conditioning. Fuel. 2012;95:263-271.

5. Frensh R, Czernik S. Catalytic pyrolysis of biomass for biofuels production. Fuel Process. Technol. 2010;91:25-32.

6. Qi Z, Jie C, Tiejun W, Ying X. Review of biomass pyrolysis oil properties and upgrading research. Energ. Convers. Manage. 2007; 48: 87-92.

7. Akhtar J, Amin, SN. A review on operating parameters for optimum liquid oil yield in biomass pyrolysis. Renew. Sust. Energ. Rev. 2012;16:5101-5109.

8. Demiral I, Sensoz S. The effects of different catalysts on the pyrolysis of industrial wastes (olive and hazelnut bagasse). Bioresource. Technol. 2008;99:8002-7.

9. Jahirul MI, Rasul A, Chowdhury A, Ashwath N. Biofuel production through biomass pyrolysis-A technological review. Energies. 2012;5:4952-5001.

10. Xiu S, Shahbazi A. Bio-oil production and upgrading research: A review. Renew. Sust. Energ. Rev. 2012;16:4406-4414.

11. Aysu T, Küçük MM. Biomass pyrolysis in a fixed-bed reactor: Effects of pyrolysis parameters on product yields and characterization of products. Energy 2014;64:1002-1025.

12. Pérez MG, Chaala A, Roy C. Co-pyrolysis of sugarcane bagasse with petroleum residue. Part I: Thermogarvemitrivc analysis. 
Fuel. 2001;80:1245-1258.

13. Sundaram EG, Natarajan E. Pyrolysis of coconut shell: An experimental investigation. J. Energ. Research. 2009;6:33-39.

14. Culcuoglu E, Unay E, Karaosmanoglu F, Angin D, Sensoz S. Characterization of bio-oil of Rapeseed cake. Energ. Source. 2005;27:1217-1223.

15. Sensoz S, Kaynar I. Bio-oil production from soybean (Glycine max L.); fuel properties of Bio-oil. Ind. Crop. Prod. 2006;23: 99-105.

16. Pattiya A, Suttibak S. Influence of glass wool hot vapour filter on yields and properties of bio-oil derived from rapid pyrolysis of paddy residue. Bioresour. Technol. 2012;116:107-113.

17. Yin R, Liu R, Mei Y, Fei, W, Sun X. Characterization of bio-oil and bio-char obtained from sweet sorghum bagasse fast pyrolysis with fractional condensers. Fuel. 2013;112:96-104.

18. Westerhof R, Kuipers N, Kersten S, van Swaaj W. Controlling the water content of biomass fast pyrolysis oil. Ind. Eng. Chem. Res. 2007;46:9238-47.

19. Pasiecznik N, Felker P, Harris P, Hasrsh I, Cruz G, Tewari J, et al. The Prosopis juliflora- prosopis pallida complex: a monograph. Conventry, UK: HDRA; 2001.

20. Locci E, Laconi S, Pompei R, Scano P, Lai A, Marincola C. Wheat bran biodegradation by Pleurotus ostreatus: A soild-state Carbon-13 NMR study. Bioresour. Tenhnol. 2008;99:4279-84.

21. Jung SH, Kang BS, Kim JS. Production of bio-oil from rice straw and bamboo sawdust under various reaction conditions in a fast pyrolyis plant equipped with a fluidized bed and a char separation system. J. Anal. Appl. Pyrol. 2008;82:240-247.

22. Greenhalf CE, Nowakowski DJ, Harms AB, Titiloye JO, Bridgwater AV. A comparative study of straw, perennial grasses and hardwoods in terms of fast pyrolysis products. Fuel. 2013;108:216-230.

23. Sharma RK, Wooten JB, Baliga VL, Lin X, Chan WG, Hajaligol MR. Characterization of chars from pyrolysis of lignin. Fuel. 2004;83:1469-1482.

24. Gani A, Naruse I. Effect of cellulose and lignin content on pyrolysis and combustion characteristics for several types of biomass. Renew. Energ. 2007;32:649-661.

25. Qadeer R, Hanif J, Saleem MA, Afjal M. Characterisation of activated charcoal. J. Chem. Soc. Pakistan. 1994;16:229-235.

26. Keiluweit M, Nico PS, Johnson MG, Kleber M. Dynamic molecular structure of plant biomass-derived black carbon (biochar).
Environ. Sci. Technol. 2010;44:1247-1253.

27. Kim KH, Kim JY, Cho TS, Choi JW. Influence of pyrolysis temperature on physiochemical properties of biochar obtained from the fast pyrolysis of pitch pine (Pinus rigida). Bioresour Technol. 2012;118:158-162

28. Al- Wabel MI, Al-Omran A, El-Nagar AH, Nadeem M, Usman ARA. Pyrolysis temperature induced changes in characteristics and chemical composition of biochar produced from conocarpus wastes. Bioresour. Technol. 2013;131:374-379.

29. Ates F, Putun E, Putun AE. Fast pyrolysis of sesame stalk: yields and structural analysis of bio-oil. J. Anal. Appl. Pyrol. 2004;71:779-790.

30. Putun AE, Ozcan A, Putun E. Pyrolysis of hazelnut shells in a fixed-bed tubular reactor: yields and structural analysis of bio-oil. J. Anal. Appl. Pyrol. 1999;52:3-49.

31. Demiral I, Eryazici A, Sensoz S. Bio-oil production from pyrolysis of corncob (Zea mays L.). Biomass Bioenerg. 2012;36:43-49.

32. Laresgoiti MF, Caballero BM, Marco ID, Torres A, Cabrero MA, Chomon MJ. Characterization of the liquid products obtained in tyre pyrolysis. J. Anal. Appl. Pyrol. 2004;71:917e34.

33. Feng ZX, Lu ZJ, Xiang GQ, Shi ZQ. Pyrolysis of rice husk and saw dust for liquid fuel. J. Environ. Sci. 2006;18:392-396.

34. Sipila K, Kuoppala E, Fagernas L, Oasmaa A. Characterisation of biomass-based flash pyrolysis oils. Biomass Bioenerg. 1988;14:103-113.

35. Ji-Lu Z, Wei-ming Y, Na-na W. Bio-oil production from cotton stalk. Energ. Convers. Manage. 2008;49:1724-1730.

36. Gercìa-Perèz M, Chaale A, Pakdel H, Kretschmer D, Roy C. Vacuum pyrolysis of softwood and hardwood pyrolysis of biomass. Comparison between product yields and bio-oil properties. J. Anal. Appl. Pyrol. 2007;78:104-16.

37. Effendi A, Gerhauser H, Bridgwater A. Production of renewable phenolic resins by thermochemical conversion of biomass: a review. Renew. Sust. Energ. Rev. 2008;12:2092-116.

38. Özbay N, Varol EA, Uzun BB, Putun AE. Characterisation of bio-oil obtained from fruit pulp pyrolysis. Energy. 2008;33: 1233-1240.

39. Li L, Zhang H, Zhuang H. Pyrolysis of waste paper: Characterisation and composition of pyrolysis oil. Energ. Source. 2005;27:867-873. 